\title{
Correction to: Moving beyond the classic diferencein-diferences model: a simulation study comparing statistical methods for estimating efectiveness of state-level policies
}

Beth Ann Grifn 1*, Megan S. Schuler ${ }^{1}$, Elizabeth A. Stuart ${ }^{2}$, Stephen Patrick ${ }^{3}$, Elizabeth McNeer ${ }^{3}$, Rosanna Smart ${ }^{4}$, David Powell ${ }^{1}$, Bradley D. Stein ${ }^{5}$, Terry L. Schell ${ }^{4}$ and Rosalie Liccardo Pacula ${ }^{6}$

Correction to: BMC Med Res Methodol 21, 279 (2021) https://doi.org/10.1186/s12874-021-01471-y

Following publication of the original article [1], the authors noticed a typographical error on the name of one of the authors on this article. The author name "Bradley D. Stei should be Bradley D. Stein". The original article has been updated.

\section{Author details}

${ }^{1}$ RAND Corporation, 1200 South Hayes Street, Arlington, VA 22202, USA. ${ }^{2} J o h n s$ Hopkins Bloomberg School of Public Health, Baltimore, MD 21205, USA. ${ }^{3}$ Vanderbilt University Medical Center and School of Medicine, Nashville, TN 37232, USA. ${ }^{4}$ RAND Corporation, Santa Monica, CA 90401, USA. ${ }^{5}$ RAND Corporation, Pittsburgh, PA 15213, USA. ${ }^{6}$ University of Southern California, Los Angeles, CA 90089, USA.

Published online: 30 January 2022

\section{Reference}

1. Griffin BA, Schuler MS, Stuart EA, et al. Moving beyond the classic difference-in-differences model: a simulation study comparing statistical methods for estimating effectiveness of state-level policies. BMC Med Res Methodol. 2021;21:279. https://doi.org/10.1186/s12874-021-01471-y.

The original article can be found online at https://doi.org/10.1186/s12874021-01471-y.

*Correspondence: bethg@rand.org

${ }^{1}$ RAND Corporation, 1200 South Hayes Street, Arlington, VA 22202, USA

Full list of author information is available at the end of the article original author(s) and the source, provide a link to the Creative Commons licence, and indicate if changes were made. The images or other third party material in this article are included in the article's Creative Commons licence, unless indicated otherwise in a credit line to the material. If material is not included in the article's Creative Commons licence and your intended use is not permitted by statutory regulation or exceeds the permitted use, you will need to obtain permission directly from the copyright holder. To view a copy of this licence, visit http://creativecommons.org/licenses/by/4.0/. The Creative Commons Public Domain Dedication waiver (http://creativeco mmons.org/publicdomain/zero/1.0/) applies to the data made available in this article, unless otherwise stated in a credit line to the data. 